\title{
Genus Pouteria: Chemistry and biological activity
}

\author{
Cíntia A. M. Silva, Luiz A. Simeoni, Dâmaris Silveira* \\ Faculdade de Ciências da Saúde, Universidade de Brasília, Campus Universitário Darcy Ribeiro, Asa Norte, \\ 70910-900 Brasília-DF, Brazil
}

\begin{abstract}
RESUMO: “Gênero Pouteria: Química e atividade biológica”. O gênero Pouteria pertence à família Sapotaceae e pode ser encontrado em muitos continentes. As plantas desse gênero têm sido utilizadas na construção civil, na alimentação e também na medicina popular. Algumas atividades biológicas são reportadas às espécies desse gênero, tais como, antioxidante, anti-inflamatória, antibacteriana e antifúngica, mas seu real potencial como fonte de novos fármacos ainda é pouco conhecido. Assim, uma revisão sobre a composição química e as atividades biológicas de Pouteria é apresentada, com o intuito de estimular a continuação dos estudos das espécies aqui citadas, e a investigação de outras espécies para as quais não foram encontrados relatos.
\end{abstract}

Unitermos: Pouteria, Sapotaceae, triterpenos, flavonoides, plantas medicinais.

\begin{abstract}
The genus Pouteria belongs to the family Sapotaceae and can be widely found around the World. These plants have been used as building material, as food, because the eatable fruits, as well as remedies in folk medicine. Some biological activities have been reported to species of this genus such as antioxidant, anti-inflammatory, antibacterial and antifungal. However, the real potential of this genus as source of new drugs or phytomedicines remains unknown. Therefore, a review of the so far known chemical composition and biological activities of this genus is presented to stimulate new studies about the species already reported moreover that species have no reference about chemistry or biological activities could be found until now.
\end{abstract}

Keywords: Pouteria, Sapotaceae, triterpene, flavonoid, medicinal plants.

\section{INTRODUCTION}

The Sapotaceae family is subdivided into five tribes with 53 genera and about 1,250 species, with a worldwide distribution, mainly in the tropical and subtropical regions of Asia and South America (Swenson \& Anderberg, 2005). The genus Pouteria Aublet is a pan tropical group consisting in 9 sections and 325 species (Triono et al., 2007). Many of them produce high-quality timber and edible fruit, representing a great economic value. Besides their commercial significance, several species have been used in folk medicine for several purposes. So far, however, few species were studied about chemistry composition or biological properties. Therefore, this report covers the chemical and biological activity studies of the species belonging to this genus until now.

\section{Chemical composition of Pouteria species}

Triterpenes and flavonoids are the main constituents of this genus. Some of them have been found in regular basis in all here considered species. Usually, triterpenes has been isolated as long chain or acetate esters. Besides, long chain hydrocarbons, alcohols, acids and esters also are found mainly in species occurring in dry regions, for example, Brazilian savannah (David, 1993; Lopez, 2005; Silva, 2007). In addition, Pouteria species have been evaluated as enzymes sources to be used as synthesis reagent as well as biological activity purposes (Lott \& Jackes, 2001; Solis et al., 2004; Hernandez et al., 2006). The mainly compounds isolated from each species are showed at Figure 1 and Table 1.

Pouteria torta (Mart.) Radlk is one of the most studied species. From hexane and dichloromethane extract of flowers and fruits (David, 1993) were isolated $\alpha$ - and $\beta$-amyrin $(\mathbf{1}, \mathbf{2})$, also isolated from the leaves (Lopez, 2005), besides lupeol (3), taraxasterol (4), pseudotaraxasterol (5), cycloartenol (6), lanosterol (7), lanosta-7,24-dien (8) and erythrodiol palmitate (9a). Fatty acids, triglycerides and normal and branched hydrocarbons also were isolated from these extracts (David, 1993).

Pouteria torta branches presented $\alpha$-amyrin acetate (1a), $\beta$-amyrin acetate (2a), betulinic acid (10) and ursolic acid (11), isolated from methanol extract (Che et al., 1980). Hexane extract from leaves gave lupeol acetate (3a) (Perfeito et al., 2005) and from ethanol extract was isolated a mixture of $\alpha$ - and $\beta$-friedelinol $(\mathbf{1 3}, 14)$ (Lopez, 2005).

Betulinic (10) and ursolic acids (11), as well as $\alpha$ - and $\beta$-amyrin acetate (1a, 2a) also were isolated from cortex of Pouteria tomentosa (Roxb.) Baehni (Anjaneyulu, 1965).

The phytochemical study of the benzene extract from Pouteria caimito (Ruiz \& Pav.) Radlk. fruits showed the presence of $\alpha$-amyrin (1), lupeol (3), erythrodiol (9), and dammarenediol (15); and from the barks extract, taraxerol (16) and its acetate (16a), 
Table 1. Pouteria species chemically researched until 2008.

\begin{tabular}{|c|c|c|}
\hline Species & Compound & References \\
\hline Pouteria caimito (Ruiz \& Pav.) Radlk. & $1,3,9,15,16,16 a, 16 b, 17,18,26$ & (Pellicciari et al., 1972; Maia et al., 2003) \\
\hline Pouteria cambodiana (Pierre ex & 24 & (Manocroi ot al $2005 \cdot 2006$ ) \\
\hline Dubard) Baehni & & 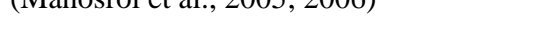 \\
\hline Pouteria campechiana (Kunth) Baehni & 20, 21, 21a, 21b, 21c, 22, 23, 24 & (Ma et al., 2004) \\
\hline Pouteria gardnerii (Mart. \& Miq.) & 12 1а За $10,11,12$ & (Silva 2007) \\
\hline Baehni & & $(\mathrm{Nilva}, 2007)$ \\
\hline $\begin{array}{l}\text { Pouteria mammosa (L.) Cronquist (sin. } \\
\text { Achras mammosa L. and Calocarpum } \\
\text { mammosum Pierre) }\end{array}$ & 9,42 & $\begin{array}{l}\text { (Bondioli \& Folegatti, 1996; Takeda et } \\
\text { al., 1997; Miller et al., 2006) }\end{array}$ \\
\hline Pouteria pariry (Ducke) Baehni & 26 & (Maia et al., 2003) \\
\hline $\begin{array}{l}\text { Pouteria sapota (Jacq.) H. E. Moore } \\
\text { et Stern (Calocarpum sapota ( Jacq. ) } \\
\text { Merr. and Sideroxylon sapota Jacq.) }\end{array}$ & $20,21,21 a, 21 b, 21 c, 23,42,43,43 a$ & $\begin{array}{l}\text { (Takeda et al., 1997; Ma et al., 2004; } \\
\text { Miller et al., 2006; Pino et al., 2006) }\end{array}$ \\
\hline Pouteria splendens (A. DC.) Kuntze & $\begin{array}{l}27,28,29,30,31,32,33,34,35,36,37 \\
38,39,40,41\end{array}$ & (Sotes et al., 2006) \\
\hline outeria subrotata Cronquist & 42 & (Miller et al., 2006) \\
\hline Pouteria venosa (Mart.) Baehni & $4,11,16,18,19,19 a$ & (Montenegro et al., 2006) \\
\hline $\begin{array}{l}\text { Pouteria viridis (Pittier) Cronquist } \\
\text { (sin. Calocarpum viride Pittier) }\end{array}$ & 20, 21, 21a, 21b, 21c, 22, 23 & (Ma et al., 2004) \\
\hline Pouteria vitiensis (Gillespie) O.Deg. & $18,24 a, 25$ & (Cambie et al., 1997) \\
\hline Pouteria tomentosa (Roxb.) Baehni & 1a, 2a, 10, 11 & (Anjaneyulu, 1965) \\
\hline Pouteria torta (Mart.) Radlk. & $\begin{array}{l}\text { 1, 1a, 2, 2a, 3, 3a, 4, 5, 6, 7, 8, 9a, 10, 11, } \\
13,14,22,23,24,25\end{array}$ & $\begin{array}{l}\text { (Che et al., 1980; David, 1993; Lopez, } \\
\text { 2005; Perfeito et al., 2005) }\end{array}$ \\
\hline
\end{tabular}

taraxenona (16b) and $\beta$-sitosterol (17) (Pellicciari et al., 1972). From hexane extract of the leaves was extracted spinasterol (18) (forthcoming paper), also present in Pouteria venosa (Mart.) Baehni leaves and stem barks and in the Pouteria vitiensis (Gillespie) O.Deg. heartwood (Cambie et al., 1997). Erythrodiol (9) also was isolated from Pouteria mammosa (L.) Cronquist (Bondioli \& Folegatti, 1996).

Pouteria venosa leaves and stem bark ethanol extracts gave ursolic acid (11) and taraxerol (16), respectively. From ethanol extract of stems were isolated miriantic acid (19) and 19 $\alpha, 23$-dihydroxyursolic acid (19a) (Montenegro et al., 2006).

Hexane extract from Pouteria gardnerii (Mart. $\&$ Miq.) Baehni leaves gave $\alpha$ - and $\beta$-amyrin $(1,2)$, $\alpha$-amyrin acetate (1a), ursolic acid (11) lupeol acetate (3a), and oleanolic acid (10) (Silva, 2007).

The methanol extracts of fruits from Pouteria campechiana (Kunth) Baehni, Pouteria sapota (Jacq.) H. E. Moore \& Stern and Pouteria viridis (Pittier) Cronquist gave gallic acid (20), (+)-gallocatechin (21), (+)-catechin (21a), (-)-epicatechin (21b), (+)-catechin3-O-gallate (21c), dihydromyricetin (22) and myricitrin (23) (Ma et al., 2004). Myricitrin (23) was also isolated from $P$. torta (forthcoming paper). Pouteria vitiensis gave vanilloyl sucrose (24a) besides myo-inositol (25) and sucrose (Cambie et al., 1997). Pouteria cambodiana (Pierre ex Dubard) Baehni contains protocatechuic acid (24) (Manosroi et al., 2005; 2006), carotenoids (Lanerolle et al., 2008) and stylbenes (Hernandez et al.,
2008).

As several Pouteria species furnish eatable fruits, the composition of the essential oil is valuable information for food sciences, and can be used to develop new flavors and brands. But as far we know, only four species were analyzed about essential oil content: Pouteria (Ducke) Baehni, P. caimito (Maia et al., 2003), P. sapota and Pouteria splendens (A. DC.) Kuntze (Sotes et al., 2006). The mainly component of volatil e oil from fruits of $P$. pariry is methyl butanoate; and the analysis of oil from $P$. caimito fruits showed that palmitic acid, hexadecil acetate and $\alpha$-copaen (26) were the most abundant constituents (Maia et al., 2003). Analysis of oil from fruits of $P$. sapota revealed the presence, besides others, of benzaldehyde, hexanal, and palmitic acid that were the major ones (Pino et al., 2006). From the almonds of these three species were isolated palmitic, estearic, oleic and linoleic acids (Solis-Fuentes et al., 2001; Solis-Fuentes \& Duran-deBazua, 2003).

By GC-MS analysis of the essential oil from $P$. splendens leaves, were identified: cis,trans- $\alpha-$ farnesol (27), trans-nerolidol (28), cis- $\beta$-elemene (29), germacrene D (30), $\beta$-selinene (31), eremophilene (32), $\delta$-cadinene (33), 10-epi- $\alpha$-cadinol (34), 10-epi- $\alpha$-muurolol (35), epi-globulol (36), globulol (37), ledene (38), palustrol (39), isophytol (40), trans-phytol (41). Also were identified: 1-octanol, 2,5-dimethylcyclohexanol, 3,5-dimethylcyclohexanol, dodecanal, tridecanal, tetradecanal, hexadecanal, 
2-decyl-oxirane, perhydrofarnesylacetone, tetradecanoic acid, hexadecanoic acid, and 9,12,15-octadecatrienoic acid ( $\alpha$-linolenic acid) (Sotes et al., 2006).

Cyanogenic compounds were detected on leaves, fruits and seeds of the Pouteria subrotata Cronquist and P. torta (Miller et al., 2006), and in leaves of $P$. amygdalicarpa and $P$. campechiana (Thomsen \& Brimer, 1997). Lucumin (42) was isolated from seeds of $P$. sapota, P. mammosa and was found in leaves extracts from P. subrotata (Takeda et al., 1997; Miller et al., 2006). Additionally, lucuminic acid (43) and lucuminamide (43a) were isolated from $P$. sapota (Takeda et al., 1997).

Other interesting compound, pouterin, a protein with lectin-like activity, was isolated from the seeds of P. torta (Boleti et al., 2007).

\section{Biological activities of Pouteria species}

Several Pouteria species have been used in folk medicine to treat fever, inflammation, skin eruptions, ulcers, diabetes (Ma et al., 2004; Montenegro et al., 2006) diarrhea (Perfeito et al., 2005), nausea, vomiting, back pain, and to promote lactation on milk feeding mothers (Manosroi et al., 2006). However, there is a lack of scientific evidence for most of these claimed biological activities.

On the other hand, the secondary metabolites present in this genus can explain some of the already proved biological activities as well as the claimed ones. The presence of phenolic compounds in the Pouteria extracts can explain, at least in part, the antioxidant and radical scavenging activities presented by the more polar extracts and fractions (Rice-Evans et al., 1996). In addition, lupeol, ursolic acid and others triterpenes also have demonstrated capacity to intercept free radicals (Bracco et al., 1981; Saleem et al., 2001).

In fact, compounds belonging to both class of

Table 2. Biological activity from Pouteria species investigated until 2008.

\begin{tabular}{|c|c|c|c|}
\hline Species & Parts & Biological activity & References \\
\hline Pouteria caimito & leaves & Antioxidant & (Castro et al., 2006) \\
\hline Pouteria cambodiana & stem bark & $\begin{array}{l}\text { Imunomodulatory, antioxidant; cell } \\
\text { antiproliferative }\end{array}$ & (Manosroi et al., 2006) \\
\hline Pouteria campechiana & fruits juice & $\begin{array}{l}\text { Antioxidant and antinitrosative, } \\
\text { anti-mitotic }\end{array}$ & $\begin{array}{l}\text { (Franco, 2006; Hernandez et al., } \\
\text { 2008) }\end{array}$ \\
\hline Pouteria grandiflora & leaves & antimicrobial and DNA-damaging & (Agripino et al., 2004) \\
\hline Pouteria guianensis & wood & $\begin{array}{l}\text { subchronic embryotoxicity to } \\
\text { Crassostrea gigas }\end{array}$ & (Libralato et al., 2007) \\
\hline Pouteria pallida & - & antimicrobial & (Humason, 2005) \\
\hline Pouteria psamophila & $\begin{array}{l}\text { leaves } \\
\text { wood }\end{array}$ & $\begin{array}{l}\text { antimicrobial and DNA-damaging } \\
\text { fungicidal }\end{array}$ & $\begin{array}{l}\text { (Agripino et al., 2004) } \\
\text { (Costa et al., 2003) }\end{array}$ \\
\hline Pouteria ramiflora & leaves & $\begin{array}{l}\text { Antioxidant; anti-inflammatory and } \\
\text { antinociceptive activity; toxicity to } \\
\text { Artemia salina larvae }\end{array}$ & $\begin{array}{l}\text { (Fontes-Junior, 2004; Nunes, } \\
\text { 2004; Castro et al., 2006) }\end{array}$ \\
\hline Pouteria reticulata & barks & antimycobacterial & (Graham et al., 2003) \\
\hline \multirow[t]{2}{*}{ Pouteria sapota } & fruits juice & Antioxidant & $\begin{array}{l}\text { (Franco, 2006; Palomino et al., } \\
\text { 2006) }\end{array}$ \\
\hline & stems & trypanocidal activity in vitro & (Abe et al., 2002) \\
\hline Pouteria splendens & leaves & germination inhibition & (Bustamante et al., 2007) \\
\hline \multirow{3}{*}{ Pouteria torta } & leaves & $\begin{array}{l}\text { Antioxidant, toxicity to Artemia } \\
\text { salina larvae, antibacterial and } \\
\text { antifungal, germination and growth }\end{array}$ & $\begin{array}{l}\text { (Alves et al., 2000; Franzotti, } \\
\text { 2004; Lopez, 2005; Perfeito et } \\
\text { al., 2005; Castro et al., 2006; }\end{array}$ \\
\hline & & $\begin{array}{l}\text { inhibition, estrogen antagonism } \\
\text { antifungal and induction of human, }\end{array}$ & Nascimento et al., 2007) \\
\hline & seeds & $\begin{array}{l}\text { rabbits and rats erythrocyte } \\
\text { agglutination ability }\end{array}$ & (Boleti et al., 2007) \\
\hline \multirow[t]{2}{*}{ Pouteria venosa } & leaves & $\begin{array}{l}\text { Antioxidant, antimalarial activity } \\
\text { in vivo }\end{array}$ & (Montenegro et al., 2006) \\
\hline & leaves & anti-HIV & (Bedoya et al., 2008) \\
\hline \multirow[t]{2}{*}{ Pouteria viridis } & fruits juice & Antioxidant & $\begin{array}{l}\text { (Franco, 2006; Palomino et al., } \\
\text { 2006) }\end{array}$ \\
\hline & Stem, stem bark & antitermite & (Barbosa et al., 2007) \\
\hline
\end{tabular}



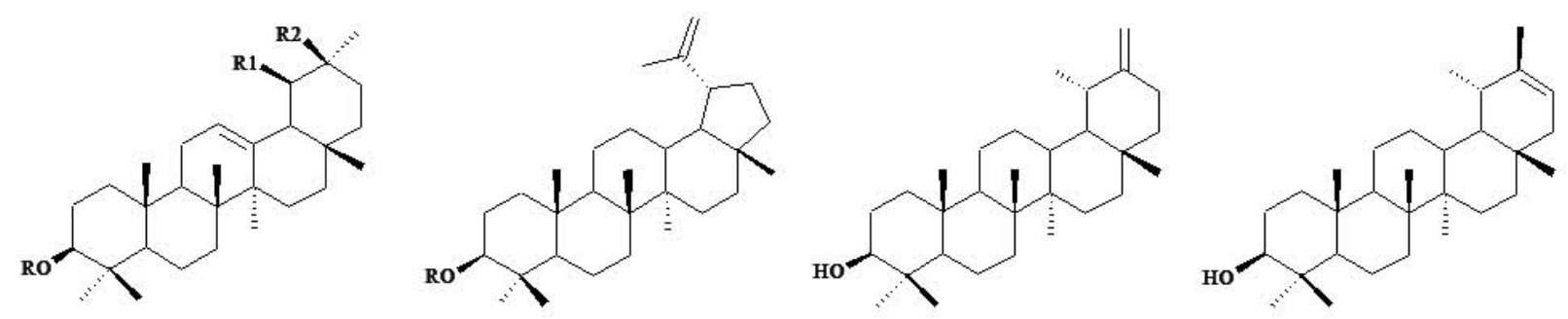

$\begin{array}{llll} & \text { R } & \text { R1 } & \text { R2 } \\ \text { 1 } & \text { H } & \text { Me } & \text { H } \\ \text { la } & \text { Ac } & \text { Me } & \text { H } \\ \text { 2 } & \text { H } & \text { H } & \text { Me } \\ \text { 2a } & \text { Ac } & \text { H } & \text { Me }\end{array}$

$\begin{array}{ll} & \mathbf{R} \\ \mathbf{3} & \mathbf{H} \\ \mathbf{3 b} & \mathbf{A c}\end{array}$
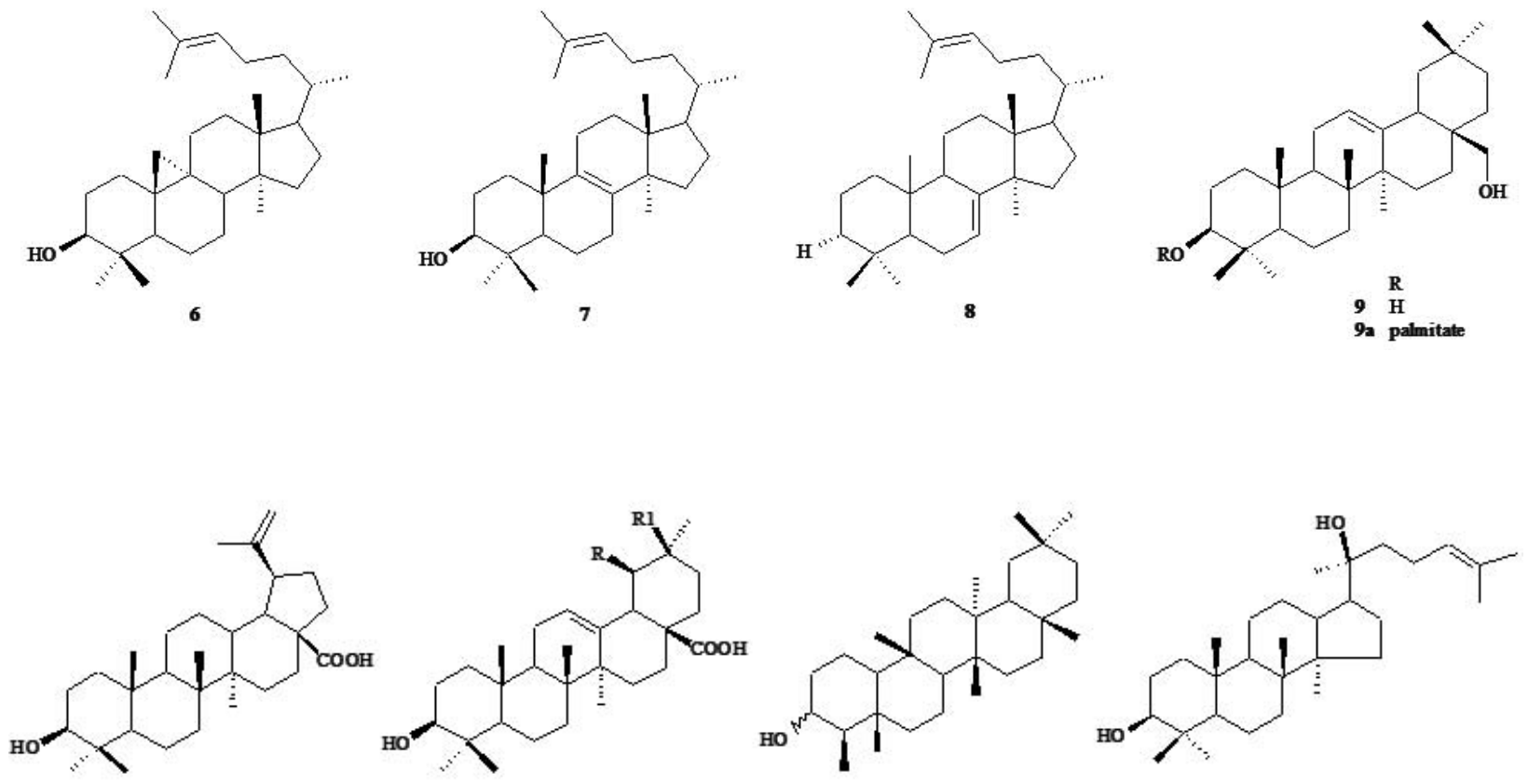

10

$\begin{array}{llll} & \mathrm{R} & \mathrm{Rl} \\ \mathbf{1 1} & \mathrm{Me} & \mathrm{H} \\ \mathbf{1 2} & \mathrm{H} & \mathrm{Me}\end{array}$

$\begin{array}{ll}13 & 3 \alpha-\mathrm{OH} \\ 14 & 3 \beta-\mathrm{OH}\end{array}$

15

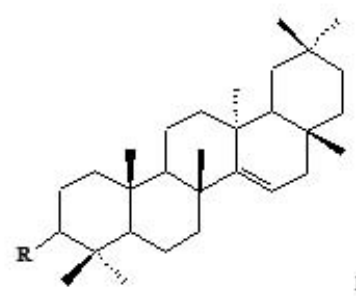

\begin{tabular}{cc}
\multicolumn{1}{c}{$R$} \\
16 & $3 \beta-\mathrm{H}$ \\
$16 \mathrm{~s}-\mathrm{OAc}$ \\
$16 \mathrm{~B}-\mathrm{Oxg}$
\end{tabular}<smiles>CCC(CC[C@H](C)C1CCC2C3CC=C4CC(CC)[C@H](C)CC[C@]4(C)C3CC[C@@]21C)C(C)C</smiles>

17

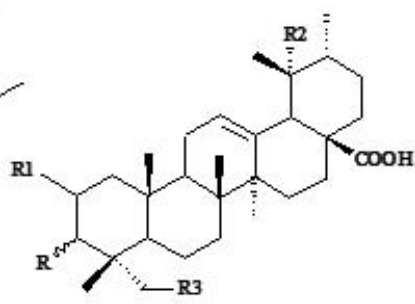

18
$19 \underset{\alpha-\mathrm{OH}}{\mathrm{R}-\mathrm{OH}} \stackrel{\mathrm{R} 2}{\mathrm{OH}} \underset{\mathrm{OH}}{\mathrm{O} 3}$ 19a $\beta-\mathrm{OH} \quad \mathrm{H} \quad \mathrm{OH} \mathrm{OH}$

Figure 1. Isolated substances from species of genus Pouteria (Sapotaceae). 
<smiles>O=C(O)c1cc(O)c(O)c(O)c1</smiles>

20<smiles>[R]Oc1cc(C(=O)OCC)ccc1O</smiles>

$\begin{array}{llc} & \mathrm{R} & \mathrm{R} 1 \\ \mathbf{2 4} & \mathrm{H} & \text { fruc-glc } \\ \mathbf{2 4 a} & \mathrm{Me} & \mathrm{H}\end{array}$<smiles>[Z]c1cc(C2CCc3c(O)cc(O)cc3O2)cc(O)c1O</smiles>

$R \quad R 1$

$21 \mathrm{OH} \quad \beta-\mathrm{OH}$

2la $\mathrm{H} \quad \mathrm{B-OH}$

2le $\mathrm{H} \quad \beta$-O-gallate<smiles>O=C1c2c(O)cc(P)cc2O[C@H](c2cc(O)c(O)c(O)c2)C1O</smiles><smiles>CC1=CCC2(C)C(C)CCC(C(C)C)C2(C)C1</smiles>

26<smiles>O=c1c(O)c(-c2cc(O)c(O)c(O)c2)oc2cc(O)cc(O)c12</smiles>

23<smiles>CC(C)=CCC/C(C)=C/CC/C(C)=C\CO</smiles>

27<smiles>C=CC(C)(O)CCC=C(C)CCC=C(C)C</smiles>

28<smiles>CC1=C[C@H]2C(=C(C)CC[C@@H]2C(C)C)CC1</smiles>

33<smiles>CC1=C[C@]2(C)C(C(C)C)CC[C@@H](O)[C@@H]2CC1</smiles>

34<smiles>C=CC1CC(C(=C)C)CC[C@@H]1C=C</smiles>

29<smiles>C=C1/C=C\C(C(C)C)C/C(C)=C\C1</smiles>

30<smiles>C=C(C)C1CCC2(C)CCCC(=C)C2C1</smiles>

31<smiles>C=C(C)C1CCC2=CCCC(C)C2(C)C1</smiles>

32<smiles>C=CC(C)(O)CCCC(C)CCCC(C)CCCC(C)C</smiles>

40

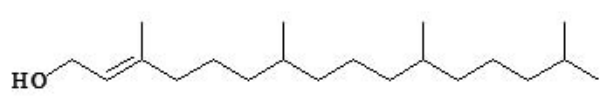

41

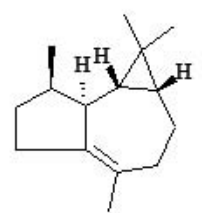

38

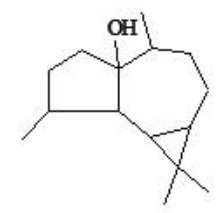

39
Figure 1. Continuation.

substances, phenolics and triterpenes, present several biological activities, since antimicrobial, cytotoxicity to anti-inflamatory and others (Ying et al., 1991; Pelzer et al., 1998; Nijveldt et al., 2001; Hodges et al., 2003; Cushnie \& Lamb, 2005; Fontanay et al., 2008).

The biological activity of the species of Pouteria is summarized in Table 2.

\section{Radical scavenging and antioxidant activities}

The acetone and hydroethanol extracts from P. campechiana fruits (Suda et al., 2005), aqueous extract from P. caimito fruits (Oliveira et al., 2007) and $P$. torta leaves and also ethanol extracts from $P$. caimito, Pouteria ramiflora (Mart.) Radlk and P. torta leaves (Castro et al., 2006) presented 1,1-diphenyl-2picrylhydrazyl (DPPH) radical-scavenging activity.

This activity was also noted at ethanol extract and some fractions from leaves, stem and stem bark of $P$. venosa (Montenegro et al., 2006), in the ethyl acetate fraction of methanol extracts from $P$. sapota and from P. viridis fruits (Ma et al., 2004; Mahattanatawee et al., 2006), and also in the methanol and acetone extracts from $P$. campechiana fruit and P. sapota juice (Franco, 2006).

The methanol extract of $P$. campechiana stem 
bark showed free radical scavenging activity in the DPPH radical assay $\left(\mathrm{IC}_{50} 0.24 \mathrm{mg} / \mathrm{mL}\right.$ ), but it was less active than ascorbic acid, butylated hydroxytoluene (BHT) and $\alpha$-tocopherol $\left(\mathrm{IC}_{50} 0.08,0.10\right.$ and $0.11 \mathrm{mg} /$ $\mathrm{mL}$, respectively). In addition, this extract at doses up to $0.073 \mathrm{mg} / \mathrm{mL}$ had no effect on lipid peroxidation (Manosroi et al., 2005).

Chloroform extract from $P$. campechiana fruits presented antioxidative and antinitrosative activities by employing two cellular experimental systems: phorbol ester-induced $\mathrm{O}_{2}$ - generation from differentiated HL-60 human promyelocytic leukemia cells; and lipopolysaccharide (LPS)-induced NO generation in RAW264.7 murine macrophages (Murakami et al., 2005). The ethyl acetate extract presented anti-mitotic activity ex vivo (Hernandez et al., 2008).

The fruits of $P$. viridis also presented antioxidant activity in the deoxyribose degradation and Fenton reaction models (Palomino et al., 2006). Six antioxidant compounds (20, 21, 21a-c, 22) were isolated and identified from the fruits of $P$. sapota; 20, 21, 21a-b and 23, from $P$. viridis fruits; and $\mathbf{2 0}$ and $\mathbf{2 1 b}$, from the fruits of $P$. campechiana (Ma et al., 2004).

\section{Immunomodulatory activity and citoxicity}

Themethanol extract from Pouteria cambodiana stem bark presented in vitro immunomodulatory activity of mouse immune system for both macrophage phagocytosis $\left(\mathrm{EC}_{50} \quad 0.02 \mathrm{mg} / \mathrm{mL}\right)$ and splenocyte proliferation ( $\mathrm{EC}_{50} 0.01 \mathrm{mg} / \mathrm{mL}$ ) (Manosroi et al., 2005; 2006).

By the in vitro phagocytic assay on nitroblue tetrazolium (NBT) dye reduction and on cellular lysosomal enzyme activity, different concentrations of aqueous and acetone extracts from P. cambodiana stem bark gave phagocytic modulation without dose response relationship, being acetone the more active extract (Manosroi et al., 2006). On the other hand, using 3-(4,5-dimethylthiazole-2-yl)-2,5-diphenyltetrazolium bromide (MTT) assay, the same extracts did not show reduction of proliferation on bone marrow cells and splenocytes (Manosroi et al., 2006). Also, the aqueous extract did not affect male body and testicular weights as well as cauda epididymal sperm counts, after 8 days treatment (Chanda et al., 2008), showing no toxicity at the tested conditions.

Hexane, ethanol and aqueous extracts from $P$. ramiflora (forthcoming paper) and $P$. torta leaves (Perfeito et al., 2005) as well as the obtained fractions from these extracts; and methanol extract from P. torta leaves (Alves et al., 2000) were evaluated about toxicity to Artemia salina larvae (Brine Shrimp Toxicity method) (Meyer et al., 1982). The aqueous fraction from ethanol extract of $P$. ramiflora and the aqueous extract from $P$. torta were toxic to A. salina (Perfeito et al., 2005). On the other hand, methanol and aqueous extracts from
$P$. caimito bark and $P$. guianensis roots and wood did not presented toxicity against $A$. franciscana larvae (Quignard et al., 2003; Libralato et al., 2007).

Hexane and ethanol extracts from $P$. ramiflora did not inhibit NO production on LPS/IFN- $\gamma$-activated J774 macrophages model and did not present cytotoxicity by MTT cell viability test (Napolitano et al., 2005).

Pouterin, from $P$. torta showed the ability to induce agglutination of human, rabbits and rats erythrocytes (Boleti et al., 2007). Also presented a remarkable activity inducing apoptosis in mammalian cells (Boleti et al., 2008).

\section{Antibacterial and antifungal activities}

The hexane and ethanol extracts from $P$. torta leaves showed antimicrobial activity against Staphylococcus aureus and Pseudomonas aeruginosa. Pseudomonas aeruginosa growth also was inhibited by the aqueous extract. Further, this extract showed activity against Escherichia coli (Lopez, 2005) and the methanol extract was active against Cladosporium sphaerospermum, E. coli, S. aureus, Bacillus cereus and P. aeruginosa (Alves et al., 2000). Pouteria pallida (C.F.Gaertn.) Baehni inhibited multidrug resistant S. aureus (Humason, 2005).

Pouterin, from $P$. torta seeds, showed antifungal activity against Fusarium oxysporum, Colletotrichum lindemuthianum and Saccharomyces cerevisiae (Boleti et al., 2007).

The pyroligeneous liquor from $P$ ramiflora wood presented fungicidal activity against Aspergillus niger and Trichoderma sp. (Costa et al., 2003).

The hydroethanol extracts from Pouteria psamophila (Mart.) Radlk. and Pouteria grandiflora (A.DC.) Radlk. leaves were evaluated for antimicrobial and DNA-damaging activities. Pouteria psamophila was active against Cladosporium cladosporioides, but inactive against C. sphaerospermum, E. coli, S. aureus and Candida albicans. On the other hand, $P$. grandiflora presented a weak activity against $C$. sphaerospermum, and was inactive against C. cladosporioides, E. coli, S. aureus and C. albicans (Agripino et al., 2004). The dichloromethane extract from Pouteria reticulata (Engler) Eyma barks presented a weak activity against Mycobacterium tuberculosis (Graham et al., 2003)

\section{Allelopathy activity}

Aqueous extract from $P$. torta leaves presented germination and growth inhibition of lettuce in a dose-dependent way (Nascimento et al., 2007) and extract from $P$. splendens leaves promoted germination inhibition of Triticum spp. (Bustamante et al., 2007).

\section{Trypanocidal and antimalarial activities}


The methanol extract from $P$. sapota stems presented trypanocidal activity in vitro $(2 \mathrm{mg} / \mathrm{mL})$ against epimastigote form of Trypanossoma cruzi (Abe et al., 2002). The ethanol extract from $P$. venosa leaves (250 mg/mL), as well as the hydroethanol fraction (500 $\mathrm{mg} / \mathrm{mL}$ ), presented antimalarial (against Plasmodium berghei) activity in vivo reducing the induced infection in rats (Montenegro et al., 2006).

\section{Insecticidal and antitermite activities}

Pouteria venosa also was evaluated about larvicidal activity. The ethanol extract did not presented activity on Aedes aegypti larvae. However, the hexaneethyl acetate (1:1) fraction killed 100\% from the larvae after 24h exposure (Montenegro et al., 2006).

Extracts from $P$. gardnerii, $P$. ramiflora and P. torta also did not present larvicidal activity against A. aegypti, Rhodnius milesi and Dipetalogaster maxi (Coelho, 2006). On the other hand, pouterin, from $P$. torta, presented insecticidal activity on Callosobruchus maculatus F. larvae (Boleti et al., 2007).

The hydroethanol extracts from $P$. guianensis stem and stem bark presented antitermite activity in repelling Nasutitermes sp. (Barbosa et al., 2007).

\section{Others}

- Several others biological activities were reported to Pouteria extracts, such as:

- Anti-inflammatory and antinociceptive activities in vivo by the ethanol extract from $P$. ramiflora leaves(Fontes-Junior, 2004; Nunes, 2004).

- Estrogen antagonist activity by hexane $P$. torta leaves when tested about agonism and antagonism on estrogen receptor beta $\left(\mathrm{ER}_{\beta}\right.$ (Franzotti, 2004).

- Anti-HIV activity by the methanol extract of $P$. viridis leaves when tested using MTT and recombinant viruses (RV) assays (Bedoya et al., 2008).

- Subchronic embryotoxicity to the oyster Crassostrea gigas by $P$. guianensis wood (Libralato et al., 2007).

Although the Pouteria genus has wide ethnobotanical tradition as food, remedies or wood to general uses, most of the available scientific information is limited to few species with economical potential as source of eatable fruits, while several other species remain without information about their pharmacological and economical potential. Indeed, most of them grow in areas suffering accelerated degradation, such as Brazilian savannah and rain forests. Therefore, considering the already isolated compounds, and the potential of Pouteria species as a resource of triterpeneand flavonoid-based material, further investigations should be carried out as part of the effort for a correct exploitation of wild species to be used as cosmetic and pharmaceutical actives.

\section{REFERENCES}

Abe F, Nagafuji S, Yamauchi T, Okabe H, Maki J, Higo H, Akahane H, Aguilar A, Jiménez-Estrada M, ReyesChilpa R 2002. Trypanocidal constituents in plants 1. Evaluation of Some Mexican plants for their trypanocidal activity and active constituents in guaco, roots of Aristolochia taliscana. Biol Pharm Bull 25: 1188-1191.

Agripino DG, Lima MEL, Silva MR, Meda CI, Bolzani VS, Cordeiro I, Young MCM, Moreno PRH 2004. Screening of brazilian plants for antimicrobial and dna-damaging activities. i. Atlantic Rain ForestEcological Station Juréia-Itatins. Biota Neotropica 4: 1-15.

Alves TMA, Silva AF, Brandão MGL, Grandi TSM, Smânia EF, Zani CL 2000. Biological screening of Brazilian medicinal plants. Mem Inst Oswaldo Cruz 95: 367373.

Anjaneyulu B 1965. Chemical investigation of some Indian plants. Indian J Chem 3: 237-238.

Barbosa AP, Nascimento CS, Morais JW 2007. Estudos de propriedades antitermíticas de extratos brutos de madeira e casca de espécies florestais da Amazônia Central, Brasil. Acta Amazonica 37: 213-218.

Bedoya LM, Alvarez A, Bermejo M, Gonzalez N, Beltran M, Sanchez-Palomino S, Cruz SM, Gaitan I, Del Olmo E, Escarcena R 2008. Guatemalan plants extracts as virucides against HIV-1 infection. Phytomedicine 15: 520-524.

Boleti AP, Freire MG, Coelho MB, Silva W, Baldasso PA, Gomes VM, Marangoni S, Novello JC, Macedo ML 2007. Insecticidal and antifungal activity of a protein from Pouteria torta seeds with lectin-like properties. J Agric Food Chem 55: 2653-2658.

Boleti APA, Ventura CA, Justo GZ, Silva RA, de Sousa ACT, Ferreira CV, Yano T, Macedo MLR 2008. Pouterin, a novel potential cytotoxic lectin-like protein with apoptosis-inducing activity in tumorigenic mammalian cells. Toxicon 51: 1321-1330.

Bondioli P, Folegatti L 1996. Caratterizzazione chimica del seme di Zapote (Lucuma mammosa). Rivista Italiana delle Sostanze Grasse 73: 229-230.

Bracco U, Löliger J, Viret J 1981. Production and use of natural antioxidants. J Am Oil Chem Soc 58: 686-690.

Bustamante RO, Marín R, Sotes G, Teillier S, Henríquez C 2007. Estructura comunitaria del matorral mediterráneo costero, Los Molles, IV Región: el rol del fuego y de la alelopatia. Biol Res 40: R-100.

Cambie RC, Ser NA, Kokubun T 1997. Heartwood constituents of Planchonella vitiensis. Biochem Syst Ecol 25: 677678.

Castro CFS, Silva CAM, Perfeito JP, Santos ML, Resck IS, Paula JE, Silveira D 2006. Avaliação da atividade antioxidante de algumas espécies de Pouteria. 29a Reunião Anual da Sociedade Brasileira de Química. Águas de Lindóia,

Chanda R, Ghosh A, Mitra T, Mohanty J, Bhuyan N, Pawankar G 2008. Phytochemical and pharmacological activity of Aegle marmelos as a potential medicinal plant: An overview. The Internet Journal of Pharmacology 6.

Che CT, Koike K, Cordell GA, Fong HHS, Dobbehstetn RH 1980. Triterpenes of Pouteria torta (Sapotaceae). J Nat Prod (Lloydia) 43: 420-421.

Coelho AAM 2006. Análise inseticida de extratos de plantas do 
bioma Cerrado sobre triatomíneos e larvas de Aedes aegyptis. Brasilia, 104 p. Faculdade de Ciências da Saúde Universidade de Brasilia.

Costa AF, Silva GF, Escudero MC 2003. Estudo comparativo entre produtos químicos preservantes e licores pirolenhosos na inibição de fungos emboloradores. Brasil Florestal 21: 24-30.

Cushnie TPT, Lamb AJ 2005. Antimicrobial activity of flavonoids. Int J Antimicrob Agents 26: 343-356.

David V 1993. Aplicação de técnicas cromatográficas na separação e determinação de triterpenos $e$ hidrocarbonetos presentes nas flores, frutos $e$ xilopódio de Pouteria torta. São Carlos, 97 p. Dissertação de Mestrado, Química, Universidade Federal de São Carlos.

Fontanay S, Grare M, Mayer J, Finance C, Duval RE 2008. Ursolic, oleanolic and betulinic acids: Antibacterial spectra and selectivity indexes. J Ethnopharmacol 120: 272-276.

Fontes-Junior EA 2004. Investigação das possíveis atividades antinociceptiva e antinflamatória do extrato etanólico de Pouteria ramiflora. Belém 110 p. Dissertação de Mestrado, Universidade Federal do Pará.

Franco EM 2006. Actividad antioxidante in vitro de las bebidas de frutas. Bebidas - Alfa Editores Técnicos Junio/ Julio: 20-27.

Franzotti EM 2004. Identificação de agonistas e antagonistas de receptores nucleares em extratos de plantas medicinais: Morus nigra L., Plectranthus ornatus Codd., Ipomoea cairica (L) Sweet e Pouteria torta (Mart.) Radlk. Brasilia, 150 p. Tese de Doutorado, Faculdade de Ciencias da Saude, Universidade de Brasilia.

Graham JG, Pendland SL, Prause JL, Danzinger LH, Schunke Vigo J, Cabieses F, Farnsworth NR 2003. Antimycobacterial evaluation of Peruvian plants. Phytomedicine 10: 528-535.

Hernandez C, Villaseñor I, Joseph E, Tolliday N 2008. Isolation and evaluation of antimitotic activity of phenolic compounds from Pouteria campechiana Baehni. Philip J Sci 137.

Hernandez L, Luna H, Solis A, Vazquez A 2006. Application of crude preparations of leaves from food plants for the formation of cyanohydrins with high enantiomeric excesses. Tetrahedron Asymmetr 17: 2813-2816.

Hodges L, Kweifio-Okai G, Macrides T 2003. Antiprotease effect of anti-inflammatory lupeol esters. Mol Cell Biochem 252: 97-101.

Humason AW 2005. A search for multi-drug resistance pump inhibitor molecules by isolation of natural products. 75 p. Master Degree Dissertation Graduate Faculty of Dedman College, Southern Methodist University.

Lanerolle M, Priyadarshani A, Sumithraarachchi D, Jansz E 2008. The carotenoids of Pouteria campechiana (Sinhala: Ratalawulu). J Nat Sci Found Sri Lanka 36.

Libralato G, Losso C, Ghirardini AV 2007. Toxicity of untreated wood leachates towards two saltwater organisms (Crassostrea gigas and Artemia franciscana). J Hazard Mater 144: 590-593.

Lopez KSE 2005. Estudo químico e atividades biológicas de Pouteria torta (Mart.) Raldk (Sapotaceae). Brasilia, 74 p. Dissertação de Mestrado, Ciências da Saúde, Universidade de Brasília.

Lott RH, Jackes BR 2001. Isozyme Analysis of rain forest plants using immature seeds. Biotropica 33: 197-204.

Ma J, Yang H, Basile MJ, Kennelly EJ 2004. Analysis of polyphenolic antioxidants from the fruits of three Pouteria species by selected ion monitoring liquid chromatography-mass spectrometry. J Agric Food Chem 52: 5873-5878.

Mahattanatawee K, Manthey JA, Luzio G, Talcott ST, Goodner K, Baldwin EA 2006. Total antioxidant activity and fiber content of select florida-grown tropical fruits. $J$ Agric Food Chem 54: 7355-7363.

Maia JGS, Andrade EHA, Zoghbi MGB 2003. Volatiles from fruits of Pouteria pariry (Ducke) Baehni and $P$. caimito (Ruiz and Pavon.) Rdlkl. Journal of Essential Oil-Bearing Plants 6: 127-129.

Manosroi A, Saraphanchotiwitthaya A, Manosroi J 2005. In vitro immunomodulatory effect of Pouteria cambodiana (Pierre ex Dubard) Baehni extract. J Ethnopharmacol 101: 90-94.

Manosroi A, Saraphanchotiwitthaya A, Manosroi J 2006. Effects of Pouteria cambodiana extracts on in vitro immunomodulatory activity of mouse immune system. Fitoterapia 77: 189-193.

Meyer BN, Ferrigni NR, Putnam JE, Jacobsen LB, Nichols DE, McLaughlin JL 1982. Brine shrimp: a convenient general bioassay for active plant constituents. Planta Med 45: 31-34.

Miller RE, McConville MJ, Woodrow IE 2006. Cyanogenic glycosides from the rare Australian endemic rainforest tree Clerodendrum grayi (Lamiaceae). Phytochemistry 67: 43-51.

Montenegro LHM, Oliveira PES, Conserva LM, Rocham EMM, Brito AC, Araújo RM, Trevisan MTS, Lemos RPL 2006. Triterpenóides e avaliação do potencial antimalárico, larvicida, anti-radicalar e anticolinesterástico de Pouteria venosa L (Sapotaceae). Rev Bras Farmacogn 16: 611-617.

Murakami A, Ishida H, Kubo K, Furukawa I, Ikeda Y, Yonaha M, Aniya Y, Ohigashi H 2005. Suppressive effects of okinawan food items on free radical generation from stimulated leukocytes and identification of some active constituents: implications for the prevention of inflammation-associated carcinogenesis. Asian Pac J Cancer Prev 6: 437-448.

Napolitano DR, Mineo JR, Souza MA, Paula JE, Espindola LS, Espindola FS 2005. Down-modulation of nitric oxide production in murine macrophages treated with crude plant extracts from the Brazilian Cerrado. $J$ Ethnopharmacol 99: 37-41.

Nascimento MC, Alcantara SF, Haddad CRB, Martins FR 2007. Allelopathic potential of Pouteria torta (Mart.) Radlk., a species of the Brazilian cerrado. Allelopathy J 20: 279-285.

Nijveldt R, van Nood E, van Hoorn D, Boelens P, van Norren K, van Leeuwen P 2001. Flavonoids: a review of probable mechanisms of action and potential applications. Am J Clin Nutr 74: 418-425.

Nunes MM 2004. Atividade antiinflamatória do extrato etanólico de Pouteria ramiflora (Mart.) Radlk., Sapotaceae. Brasília, 60 p. Dissertação de Mestrado, Ciências Médicas, Universidade de Brasília.

Oliveira G, Troncoso L, Guija E, Nunez M, Flores J, Quiroz K 2007. Capacidad antioxidante de Pouteria caimito (caimito) y Spondias mombin L. (ubos). An Fac Med Lima 68: 21.

Palomino M, Pacheco A, Valdivieso R, Guija E 2006. Determinación de las propiedades antioxidantes y prooxidantes del Calocarpum viride "zapote verde". An Fac Med Lima 67: S22.

Pellicciari R, Ardon A, Bellavita V 1972. Triterpenes from Pouteria caimito. Planta Med 22: 196-200.

Pelzer L, Guardia T, Juarez A, Guerreiro E 1998. Acute and chronic antiinflammatory effects of plant flavonoids. 
Il Farmaco 53: 421-424.

Perfeito JP, Santos ML, Lopez KSE, Paula JE, Silveira D 2005. Characterization and biological properties of Pouteria torta extracts: a preliminary study. Rev Bras Farmacogn 15: 183-186.

Pino JA, Marbot R, Sauri E, Zumarraga C 2006. Volatile components of sapote [Pouteria sapota (Jacq.) H. E. Moore et Stern] fruit. J Essent Oil Res 18: 22-23.

Quignard ELJ, Pohlit AM, Numomura SM, Pinto AC, Santos EVM, Morais SK, Alecrim AM, Pedrozo ACS, Cyrino BRB, Melo CS 2003. Screening of plants found in Amazonas state for lethality towards brine shrimp. Acta Amazonica 33: 93-104.

Rice-Evans C, Miller N, Paganga G 1996. Structure-antioxidant activity relationships of flavonoids and phenolic acids. Free Radic Biol Med 20: 933-956.

Saleem M, Alam A, Arifin S, Shah M, Ahmed B, Sultana S 2001. Lupeol, a triterpene, inhibits early responses of tumor promotion induced by benzoyl peroxide in murine skin. Pharmacol Res 43: 127-134.

Silva CAM 2007. Contribuição ao estudo químico e biológico de Pouteria gardnerii (Mart. \& Miq.) Brasília, 150 p. dissertation, Faculdade de Ciências da Saúde, Universidade de Brasília.

Solis-Fuentes JA, Duran-de-Bazua C 2003. Characterization of eutectic mixtures in different natural fat blends by thermal analysis. Eur J Lipid Sci Technol 105: 742748.

Solis-Fuentes JA, Tapia-Santos M, Duran-de-Bazua MC 2001. Oil from the zapote mamey almond, and analysis of its extraction conditions and yields. Inf Tecnol 12: 23-28.

Solis A, Luna H, Manjarrez N, Perez HI 2004. Study on the (R)oxynitrilase activity of Pouteria sapota. Tetrahedron 60: 10427-10431.

Sotes GJ, Urzua A, Sebastian B 2006. Chemistry of Pouteria splendens and its ecological situation. Biochem Syst Ecol 34: 338-340.

Suda I, Oki T, Nishiba Y, Masuda M, Kobayashi M, Nagai S, Hiyane R, Miyashige T 2005. Polyphenol contents and radical-scavenging activity of extracts from fruits and vegetables in cultivated in Okinawa, Japan. $J$ Jpn Soc Food Sci Technol 52: 462-471.

Swenson U, Anderberg AA 2005. Phylogeny, character evolution, and classification of Sapotaceae (Ericales). Cladistics 21: 101-130.

Takeda T, Gonda R, Hatano K 1997. Constitution of lucumin and its related glycosides from Calocarpum sapota Merrill. Chem Pharm Bull 45: 697-699.

Thomsen K, Brimer L 1997. Cyanogenic constituents in woody plants in natural lowland rain forest in Costa Rica. Bot J Linn Soc 124: 273-294.

Triono T, Brown AHD, West JG, Crisp MD 2007. A phylogeny of Pouteria (Sapotaceae) from Malesia and Australasia. Aust Syst Bot 20: 107-118.

Ying Q, Rinehart A, Simon S, Cheronis J 1991. Inhibition of human leucocyte elastase by ursolic acid. Evidence for a binding site for pentacyclic triterpenes. Biochem J 277: 521. 